\title{
ZOFIA SOKOLEWICZ
}

Uniwersytet Warszawski

\section{Badania terenowe jako gwarancja empiryzmu antropologii?}

Komentarz do artykułu Łukasza Kaczmarka Między survey research a obserwacją uczestniczacą: rozdarcia metodologiczno-tożsamościowe w polskiej etnologii/antropologii kulturowej w XXI wieku

$\mathrm{R}_{\mathrm{r}}^{\mathrm{e}}$ efleksja nad sposobami dochodzenia do wiedzy i ustalania ich prawomocności towarzyszy niezmiennie wszystkim badaczom. Kolejne pokolenia ponawiają pytania o zasady naszego poznania, ich skuteczność w drodze dochodzenia do prawdy. Pytania mogą być nieco inaczej sformułowane, ale zwykle chodzi o to samo: czy wiedza jest nam objawiona - w słowie, obrazie, dźwięku, w piśmie lub we śnie - tak jak objawia się muzyka niektórym Indianom Ameryki Południowej - czy dochodzimy do niej metodą prób i błędów lub jeszcze inaczej. Czy sposób ujmowania jej w słowa jest ścisły? Jak przebiega nasze rozumowanie?

W czasie moich studiów w latach 50. XX wieku pasjonowaliśmy się metodologicznym indywidualizmem Karla Raimunda Poppera. Jego Nędza Historycyzmu była antidotum na marksistowską dialektykę i teorię formacji gospodarczo-społecznych. Intrygował mnie problem indukcji i empiryzmu. To dzięki wyjazdowi do Londynu Jerzego Giedymina (UAM 1957/8) kontakt z Popperem zaowocował rozwojem filozoficznej grupy Jerzego Kmity, Leszka Nowaka, Jerzego Topolskiego i pośrednio przyczynił się - choć dopiero po wielu latach również do intensyfikacji refleksji metodologicznej w etnografii (W.J. Burszta). Pytania o prawomocność naszej wiedzy dotyczą także wiedzy pochodzącej z badań terenowych, jednego z fundamentów antropologii. I dlatego rozważania Łukasza Kaczmarka są ważne dla nas wszystkich.

Do każdej nowej teorii podchodziliśmy emocjonalnie. Wspominałam już kiedyś rozmowę z Lucy Mair, znakomitą afrykanistką, wierną uczennicą Bronisława Malinowskiego w LSE (Sokolewicz 2011: 324). Opowiadała mi z wielkim podnieceniem o tym, jak po pojawieniu się Malinowskiego w LSE i ogłoszeniu jego metody, studenci poszli gromadnie King's Rd. do Hyde Parku, gdzie 
przedstawiał swoje tezy. Wszyscy sądzili, że dzięki intensywnym badaniom terenowym została odkryta empiryczna metoda dochodzenia do prawdziwych rezultatów, zbliżenia się do prawdy o Człowieku. Byli przeciw ówczesnym autorytetom: Jamesowi G. Frazerowi i Charlesowi G. Seligmanowi. Sama mogłam obserwować w 1958 roku żywiołowe reakcje studentów London School of Economics and Political Science po grudniowym wykładzie Edmunda R. Leacha, opublikowanym później w Rethinking Anthropology (Leach 1961), w którym zakwestionował szereg tez Malinowskiego. Pamiętam też lata 70. XX wieku w Polsce, gdy młodzi gniewni, na spotkaniach w Skawicy (Benedyktowicz, Robotycki 1985), a także przy każdej innej okazji, głosili prawdę strukturalizmu, semiotyki i fenomenologii. Były to gorące dyskusje, niezmiernie krytyczne wobec pokolenia profesorów, zarówno wobec metody Kazimierza Moszyńskiego, jak i Kazimierza Dobrowolskiego, może więc dlatego najostrzejsze w Krakowie.

W ferworze dyskusji nie zauważono, że metody obu tych uczonych zostały wypracowane $\mathrm{w}$ różnych celach, tak aby uzyskać odpowiedzi na pytania odmienne od tych, które interesowały młodych gniewnych polskich uniwersytetów. Pytam więc - czy jest metoda dobra na wszystko? Na wszystkie możliwe pytania? I czy jest tylko jedna metoda badań terenowych?

Pytania zadawane przez Moszyńskiego dotyczyły genezy. Ważny był dla niego czas długi. Dobrowolski zajmował się badaniem procesu historycznego, $\mathrm{w}$ jego trwaniu szukał odpowiedzi na mechanizm zmian, interesował go czas ściśle określony, raczej średni lub wręcz krótki. Stosowanie metody Moszyńskiego do badań nad zmianą kulturową było błędem. Podobnie byłoby w odwrotnej sytuacji. Z jedną i drugą metodą łączyły się badania terenowe. W każdym z przypadków inaczej rozumiane. Nawiązywałam do tego, opisując dyskusje nad kolejnymi kwestionariuszami do Polskiego Atlasu Etnograficznego w 1953 i 1954 roku (Sokolewicz 1993: 130-131; 2010: 24, 26). Pytania kwestionariuszy były więc różne, bo inne były cele podjętego badania. I dlatego może różne raporty typu survey opracowywane są według odmiennych kwestionariuszy. A praca z kwestionariuszem nie wyklucza obserwacji uczestniczącej.

W interesującej prezentacji na Kongresie PIA Tarzycjusz Buliński (2013), wskazując na różnice między teoriami kultury (lub raczej orientacjami filozoficznymi stanowiącymi o założeniach $\mathrm{w}$ różnych teoriach), twierdził, że to, co je łączy, to są badania terenowe. To prawda, ale niezupełna. W każdej z omawianych teorii (orientacji) badania te były inaczej rozumiane. Wymienię tu tylko jedną, choć podstawową, różnicę w sposobie traktowania rozmówców: przedmiotowo lub po partnersku. I choć funkcjonalizm nie do końca przezwyciężył brak podmiotowości rozmówcy, wynikający ze wskazania Emila Durkheima, by badać stosunki społeczne jak rzeczy, to jednak jest on (badany, obserwowany, rozmówca) obecny zarówno w Argonautach Zachodniego Pacyfiku, jak i Ogrodach Koralowych. Było to skutkiem dążenia Malinowskiego, aby antropolog mówił w imieniu krajowców, niekoniecznie wysuwając ich na pierwszy plan, ale też nie ukrywając ich obecności. Dziś my chcielibyśmy oddać głos im samym. Ta prosta 
konstatacja zabrała nam sporo czasu. I jest brzemienna w skutki. Również $\mathrm{w}$ podejściu do badań terenowych.

Czy obserwację uczestniczącą uratuje zażyłość? Mam w pamięci doświadczenie Joy Hendry, która - zaprzyjaźniona ze swoją tłumaczką, przewodniczką i jak sądziła - przyjaciółką - Japonką, przekroczyła w odczuciu tej ostatniej pewną granicę bliskości, co zdecydowało o zmianie charakteru ich relacji. Każda kultura ma swoje rozumienie przyjaźni, zażyłości (Hendry 1992). Wprowadzone intuicyjnie przez Kaczmarka pojęcie „zażyłości” zasługuje niewątpliwie na głębsze zastanowienie się. Teren to nie tylko teoria, ale i życie badacza. I chodzi tu też o to, czy jesteśmy skłonni żyć w terenie podobnie do sposobu życia badanej społeczności czy też nie możemy zrezygnować z pewnych nawyków naszej kultury. W latach 50. i 60. XX wieku za dobrą i skuteczną praktykę badawczą uważano wyjazdy z rodziną. Dokumentują ją książki żon badaczy: Rosemary Firth, Laury Bohannan, Elizabeth Bowen i wielu innych. Rodzina antropologa pomagała mu "upodobnić" się do badanych, miał te same troski jako mąż i jako ojciec rodziny jak jego badani. Ponadto pozwalało to na uniknięcie kłopotliwych nieraz związków z miejscowymi kobietami. Moi koledzy z seminarium w LSE wielokrotnie przytaczali, ze znaczącym przymrużeniem oka, powiedzonka o skłonnościach niektórych antropologów do czarnych kobiet lub krytykując ich przyzwyczajenia do wygód cywilizacji, w tym np. korzystanie z pobliskich hotelików i dojeżdżanie "do terenu" lub rozbijanie namiotów z dala od zgiełku badanej wsi. Jeszcze w 1964 roku byłam świadkiem, jak na seminarium Claude Lévi-Strauss odpytywał powracającą z badań koleżankę, czy posługiwała się osobnymi, zarezerwowanymi tylko dla niej, naczyniami do mycia i jedzenia czy też korzystała ze wspólnych z rodziną, u której mieszkała. Teren to przecież też spanie, jedzenie, higiena intymna, seks... Codzienność. Pytanie - do jakiego stopnia mamy pozostać „osobni”. Czy zażyłość polega na tym, że jadamy ze wspólnych talerzy? Gdy marząc o wyjeździe do Afryki, pytałam jak mam przygotować ekspedycję, znana afrykanistka odpowiedziała mi first you must buy a lorry, Miss... Czyli, musiałam być mobilna i niekoniecznie, wzorem badanych, chodzić pieszo lub zależeć od lokalnego transportu. Odpowiedź na tego rodzaju pytania jest oczywiście różna w różnych czasach i miejscach.

Na marginesie tych rozważań dodam, że swego czasu w pełni zaakceptowałam przyjęte przez profesora Szynkiewicza tłumaczenie survey research jako badania powierzchniowe. Było to $\mathrm{w}$ czasie, gdy archeologowie na dużą skalę rozwijali tego rodzaju badania, które miały po prostu dać im przegląd tego, czego na danym stanowisku archeologicznym mogli się spodziewać. Był to przegląd analogiczny do przeglądu treści zawartych, tytułem przykładu, w serii Ethnographic Survey of Africa i podobnych. Profesor Szynkiewicz w rozmowie telefonicznej w lutym 2016 roku potwierdził tę intuicję.

Już dawno zrezygnowałam z marzeń o stworzeniu jednej, ogólnej teorii kultury i tym bardziej, jednego ścisłego języka naukowego, w tym definicji takich pojęć, jak obserwacja uczestnicząca i survey. Malinowski dążył do wypracowania takiego naukowego języka. Sądził, że funkcjonalizm jest w humanistyce 
odpowiedniością newtonowskiej fizyki. Może. Ale czy humanistyce potrzebny jest Einstein? Gdy zapoznawałam się z kolejnymi teoriami kultury, za każdym razem przenikało mnie wzruszenie, że oto mam klucz do drzwi. Ale za nimi były następne...

Krytyka kolejnych teorii powiększa nasze doświadczenie. Mamy już teraz świadomość, że dzieła człowieka (kultura?) mają charakter wielowymiarowy. Nie wszyscy jednak zgadzamy się z twierdzeniem Lévi-Straussa (2013: 28-29), że obiektywizm w antropologii oznacza nie tylko powściągnięcie własnego subiektywizmu badacza, ale też zgodę wszystkich możliwych obserwatorów w danej kwestii. Zarówno Malinowski, jak i Lévi-Strauss dążyli do ukształtowania antropologii na wzór nauk eksperymentalnych. Nie tylko oni, ale i Radcliffe-Brown, i Firth (1958) zastanawiali się, czy antropologia jest science or art? Dla Lévi-Straussa była science. I stąd takie rozumienie obiektywizmu dla wyżej wymienionych i części ich uczniów także. Z tego wynikało dążenie do utrzymania obserwacji uczestniczącej jako gwarancji empiryzmu w badaniach terenowych. I to jest podstawowa sprawa, którą $w$ dyskusjach o terenie pomijamy. Po co on nam był? Był tą wspomnianą gwarancją empiryzmu. Czy jednak uważamy się obecnie za naukę empiryczną z jej kryteriami? Czy jesteśmy w stanie powtórzyć badanie $\mathrm{w}$ identycznych warunkach? Czy zgodnie z naszymi wskazówkami może powtórzyć je $\mathrm{w}$ celu potwierdzenia dowolny badacz na świecie, tak jak to jest $\mathrm{w}$ naukach eksperymentalnych?

Młodsza generacja antropologów w dużej mierze dystansuje się od koncepcji antropologii jako science. Sięga przede wszystkim do tradycji Diltheya, do przeżycia, do doświadczenia. Nie dąży do ustalenia praw. Ta antropologia chce nie tylko obserwować zachowania człowieka i formułować prawa (co nie udało się żadnemu z antropologów, o czym pisze m.in. Ian Jarvie w Revolution in Anthropo$\log y)$, a u nas Gerhard Kloska (1981), ale też go słuchać. Nie mówić w jego imieniu, ale jak już wspominałam, oddać mu głos. Niczego nie chcemy wyjaśniać... chcemy zrozumieć. Czy jednak z tego powodu badania terenowe stały się niepotrzebne? Chyba nie. Są nadal źródłem ważnych informacji nie do zdobycia inną drogą. Przybierają bardzo różne formy, zależnie od potrzeby. I z tego powodu mogą być stosowane przez przedstawicieli różnych dyscyplin. Ale nadal pozostają naszym wkładem w historię nauki.

Pragnąć przybliżyć studentom charakter badań terenowych, posługuję się na zajęciach tekstem Joy Hendry z jej Introduction to Social Anthropology:

In all such cases, the anthropologist is observing people in what we call 'face-to-face' relations. This is a great advantage, not least because such people will talk of each other as well as themselves, and this offers sources of information which reinforce each other and go deeper than a few 'one-to-one' interviews might. More importantly still, members of such groups are likely to share a system of values, and although they might disagree with one another on specific issues, there will certainly be a set of underlying assumptions which they will draw upon in their communication with each other. It is this set of shared assumptions which 
defines in broad terms the language they use and the way they see the world through that language (Hendry 1999: 4-5).

Badania terenowe traktowano $\mathrm{w}$ antropologii jak rodzaj inicjacji, pasowania na antropologa. Czy każdy wiedział, po co jedzie i co bada? W tak cudownie dowcipny sposób opisuje to Nigel Barley w Innocent Anthropologist. Badania terenowe według Malinowskiego i pokolenia jego uczniów nie musiały charakteryzować się zażyłością, ale musiały być intensive. A więc po pierwsze, po drugie i po trzecie - długotrwałe, co najmniej rok. Z tego powodu żaden $\mathrm{z}$ moich zachodnich kolegów nie uważał mnie za badacza terenowego. Tak jak wszyscy polscy etnografowie wielokrotnie wyjeżdżałam $w$ teren, do niektórych wsi powracałam wiele razy, zarówno w czasie badań Polskiego Atlasu Etnograficznego, przygotowań do Międzyuczelnianych Obozów Etnograficznych, badań Kurpiowszczyzny, pobytu w Bretanii, ekspedycji mongolskich, pobytów w Serbii, Macedonii i Bułgarii. Każdy z wyjazdów owocował nowymi pytaniami i inspirował do przemyśleń teoretycznych, ale nie był intensive. Nie, nie czuję się badaczem terenowym, choć wyjeżdżałam w teren. Moja generacja nie miała szans (a może i nie czuła potrzeby) na naprawdę intensywne badania terenowe, choć i tu były wyjątki. Takie badania na pewno prowadziła przed 1939 rokiem profesor Zawistowicz-Adamska i potem w Trześniowie Anna Kutrzeba-Pojnarowa, prowadził je Włodzimierz Wincławski (jako pedagog) we wsiach kolo Nowego Targu i kolo Płocka gdzie najpierw on, potem jego żona, pracowali w szkole, byli częścią społeczności. Prowadził je profesor Wojciech Bęben. Te badania były na pewno intensywne, choć nie odbiły się $\mathrm{w}$ środowisku takim echem, jakim powinny. Badania mojego pokolenia to ekspedycje, wyjazdy w czasie przerw $\mathrm{w}$ roku akademickim, wyjazdy często do tych samych miejsc. Nie spełniały jednak warunku ciągłości w tym samym czasie. Dla mojego pokolenia wzorem badacza terenowego był Andrzej Waligórski jako badacz Luo. Wśród polskich etnografów większość zasługuje na miano terenowców. Każdy ośrodek uniwersytecki i muzea prowadziły badania terenowe. Te badania miały różny charakter: badania pilotażowe, badania typu atlasowego, stacjonarne, ekspedycje... Każdorazowo dostosowane do rodzaju pytania, jakie sobie stawiali badacze.

Intensywność badań antropologicznych w XX w. wynikała w dużej mierze $\mathrm{z}$ tego, że były one jedynym sposobem zgromadzenia źródeł o niepiśmiennych społeczeństwach. Miały one też dodatkowe uzasadnienie natury etycznej. Wielu antropologów podejmowało badania, mając na celu pokazanie, że tak zwani "dzicy" są ludźmi takimi jak wszyscy pozostali. Pamiętam, jakie wrażenie wywarł na mnie opis zachowań Tlingitów uczyniony przez F. Boasa, w którym podkreślił, że śmieją się i płaczą tak jak my! Założenie o równości kultur przyjął też Malinowski. Ludzie są różni, ale równi. To miała potwierdzić obserwacja antropologiczna, która była rękojmią prawdziwości zebranych informacji, antropolog był świadkiem, od którego nikt nie odbierał przysięgi, ale ją zakładał. Dlatego wszelkie próby fałszerstw były traktowane jako skandal, sprzeniewierzenie się powołaniu. Uniwersytet w Chicago dlatego odebrał stopień doktora 
Carlosowi Castanedzie. Przecież coś ze średniowiecznej struktury nauki realizowanej głównie przez duchownych, pozostało w naszym o niej myśleniu, w przysiędze doktorskiej powtarzamy „... non sordidi lucri causa... sed quo magis veritas propagetur...".

Od czasów Malinowskiego przeżyliśmy zwrot lingwistyczny, literacki, performatywny... zauroczyła niektórych z nas teoria sprawczości i dyskursu... odkryliśmy podmiotowość badanego, znaczenie jednostki... Sformułowaliśmy wiele nowych pytań i do nich dostosowujemy metody, w tym badania terenowe. Nie są one już gwarantem empirycznego charakteru antropologii, ale źródłem poznania, które - $\mathrm{z}$ większą pokorą - uznajemy za nie tak pewne, obarczone błędem, formą narracji, naszym subiektywizmem. Interesujemy się bardziej indywidualnym doświadczeniem niż grupą, a representations collectives mają dla nas bardziej ograniczone znaczenie niż kiedyś, choć z nich nie rezygnujemy całkiem. Zaczerpnęliśmy wiele z całej humanistyki. Nie jesteśmy już wyróżniani zależnie od tego, jaki badamy „lud” czy „plemię”, Trobriandczyków, Nuerów, Tikopia, Tallensi... kto jest dla nas tym eksperymentalnym Człowiekiem, kluczem do wiedzy o całym gatunku, jak to sobie wyobrażał Malinowski.

Kim jesteśmy, czym się zajmujemy? Jesteśmy jedną z nauk o kulturze, częścią humanistyki, refleksji nad człowiekiem, Kaczmarkiem, Bulińskim, Majbrodą, Buchowskim, Sokolewicz... Czy musimy się bliżej określać? Wiemy kim jesteśmy, zaprotestujmy przeciw biurokracji, która nas klasyfikuje, dzieli, ogłupia, daje pieniądze ze względu na nazwę. Korzystajmy ze wszystkiego, co niesie tradycja i daje otaczający nas świat, podkreślajmy znaczenie i wagę stosowanych przez nas metod. Tłumaczmy to innym, którzy może nadal stereotypowo myślą, że nasze badania to "to, co jedna pani powiedziała drugiej pani". Nauka i jej przedmiot zmienia się, klasyfikacje nauk wypracowane w nowożytności też nie są wieczne. Utrwalanie starego porządku jest bez sensu. Walczmy o swoje z otwartą przyłbicą. Nazywam się jak się nazywam i robię to, co robię.

\section{Literatura}

Benedyktowicz, Z., Robotycki, C. (red.) (1985). Szkice i próby etnograficzne. Materiały z sesji naukowych, Studenckie Zeszyty Naukowe Uniwersytetu Jagiellońskiego IV. Zeszyty Etnograficzne, z. 1, Kraków.

Buliński, T. (2013). Nasze metodologiczne minimum. Rozwój metodologii w antropologii, wystąpienie konferencyjne na I Polskim Kongresie Antropologicznym, PIA, Warszawa.

Firth, R. (1958). Social Anthropology as Science and as Art, Dunedin: University of Otago.

Hendry, J. (1992). The Paradox of Friendship in the Field. Analysis of a Long-Term Anglo-Japanese Relationship. W: J. Okely, H. Callaway (eds.), Anthropology and Autobiography (pp. 163-174). London, New York: Routledge.

Hendry, J. (1999) An Introduction to Social Anthropology: Other People's Worlds, Basingstoke: Macmillan.

Kloska, G. (1981). Falsyfikacjonizm K.R. Poppera a twierdzenia etnologii, Etnografia Polska, $X X V(1), 29-46$. 
Lévi-Strauss, C. (2013). Antropologia wobec problemów wspótczesnego świata. Przeł. M. Falski. Kraków: Wydawnictwo Uniwersytetu Jagiellońskiego.

Leach, E.R. (1961). Rethinking Anthropology, London: University of London.

Popper, K.R. (1996). Wszechświat Otwarty Argument na rzecz indeterminizmu. Przeł. A. Chmielewski, Kraków: Znak.

Sokolewicz, Z. (1993). Pług i płużyca. W: J. Bohdanowicz (red.), Komentarze do Polskiego Atlasu Etnograficznego, t. I, Rolnictwo i hodowla (s. 130-131), Warszawa: Polskie Towarzystwo Ludoznawcze.

Sokolewicz, Z. (2010). Rewolucja, konflikt pokoleń czy kumulacja doświadczeń - zmiana pytań badawczych w etnografii polskiej po II wojnie światowej. W: A. Malewska-Szałygin, M. Radkowska-Walkowicz (red.), Antropolog wobec wspótczesności (s. 15-35), Warszawa: Wydawnictwa Uniwersytetu Warszawskiego.

Sokolewicz, Z. (2011). Moje życie naukowe można sprowadzić do próbowania kolejnego klucza z wielkiego pęku, który dała mi teoria poznania, odpowiedzi na pytania Zbigniewa Jasiewicza, Lud, 95, 303-354.

\section{SUMMARY}

Can fieldwork ensure anthropology's empiricism?

This paper addresses the influence of a research method on the identity of anthropology as a discipline. Using my own academic biography as a point of departure, I would like to situate this issue in a wide historical perspective in order to show that its contemporary definitions have emerged from questions already present in the discipline's past concerns. This paper suggests that deliberations on the anthropological method are anchored in a model of academic disciplines grounded in their specific methods. As a result, a discussion about fieldwork can in fact be considered to be a discussion about a model of doing anthropology. This understanding allows for an explanation of the discrepancies in understanding ethnographic research methods at different moments in the history of cultural anthropology.

Keywords: ethnographic fieldwork, history of cultural anthropology, models of academic disciplines 